\title{
COMPARATIVE STUDY OF SKIN FOLDING OF DOMINANT AND NONDOMINANT HEMIBODIES IN SPASTIC HEMIPLEGIC CEREBRAL PALSY
}

\author{
Osmair Gomes de Macedo, João Gilberto Carazzato, ${ }^{\mathrm{II}}$ Eduardo de Souza \\ Meirelles, "I Adilson de Paula," Carlos Alberto dos Santos, "I Raul Bolliger Neto,"I \\ Rames Mattar Júnior II
}

doi: 10.1590/S1807-59322008000500006

Macedo OG, Carazzato JG, Meirelles ES, Paula A, Santos CA, Bolliger-Neto R, Mattar-Júnior R. Comparative study of skin folding of dominant and nondominant hemibodies in spastic hemiplegic cerebral palsy. Clinics. 2008;63(5):601-6.

OBJECTIVE: To compare skin folds in the dominant and nondominant halves of the body in a group (A) of 20 individuals with cerebral palsy and spastic hemiplegia and a group (B) of 30 normal volunteers.

METHOD: Body mass, height and skin folds were measured, and the percentage of body fat was estimated by adipose tissue measurement and densitometry. The mean age in group (A) was 24.6 \pm 5.6 years (ranging from 16.1 to 38.1 years). The mean age in group (B) was $25.3 \pm 3.8$ years (ranging from 19.0 to 34.11 years).

RESULTS: Statistically significant differences were observed between the dominant and nondominant halves of the body for biceps, triceps, thoracic, suprailiac, thigh and midcalf skin folds in group A; the biceps, subscapular, midaxillary, suprailiac, abdominal, thigh and midcalf skin folds in group B; and the percentage fat obtained by adipose tissue measurement in both groups. Statistically significant differences were observed for the triceps skin fold when the dominant halves of the body in groups A and B were compared. Statistically significant differences were also observed for the biceps, triceps, thigh and midcalf skin folds as well as the adipose tissue measurements between the dominant and nondominant halves of the body in the two groups. The percentage fat as estimated by densitometry was significantly correlated with the adipose tissue measurement.

CONCLUSION: There were statistically significant differences between the skin folds in the dominant and nondominant halves of the body, both in group A and in group B (greater in group A). There was a statistically significant correlation in the percentage fat as estimated by densitometry and as measured by adipose tissue in groups A and B.

KEYWORDS: Muscle spasticity; Weight-height; Body composition; Adipose tissue measurement; Densitometry.

\section{INTRODUCTION}

In recent years, there has been increasing awareness of the importance of physical activity for reintegrating handicapped individuals into society, as well as the importance of competitive sports activities for such individuals. However, most studies on this topic have highlighted spinal injuries and neglected other populations,

\footnotetext{
I Universidade Sant'Anna - São Paulo/SP, Brazil.

II Department of Orthopedics, Faculdade de Medicina da Universidade de São Paulo - São Paulo/SP, Brazil.

Phone: 11556453.4958

Email: osmairfisio@uol.com.br

Received for publication on April 15, 2008.

Accepted for publication on June 20, 2008.
}

particularly children and adults with cerebral palsy. ${ }^{1}$

To determine the physical aptitude of each individual for whom physical exercise activities are proposed and to prescribe individualized and safe physical activities, physical evaluation methods are needed. Body composition analysis should be included in such physical evaluations, since it is important that programs be specific for each individual.

The term "body composition" has almost always been related to body fat estimates based on a simple division of the body into two components: fatty and lean mass. The relative quantity of fat in the body is, by far, the most common measurement of body composition for adults and children, because of the relationship between obesity and the predisposition to a wide variety of illnesses as well as the relationship between obesity, health and athletic 
performance. ${ }^{2}$ Elite athletes, people seeking to achieve or maintain an ideal body mass and patients in hospitals have all benefited from the increased popularity and precision of body composition evaluations, ${ }^{3}$

Obesity has been defined as excess of fat content contributing to the whole-body weight, not just excessive weight in relation to a given height, ${ }^{4}$ It is a secondary or contributory risk factor for the development of coronary diseases, arterial hypertension, diabetes and hyperlipidemia. ${ }^{5}$

The ideal body mass is only a guide; it is not a target for handicapped individuals. Furthermore, it is difficult to determine the true height of patients who have developed significant deformities of the vertebral column, hips, knees and ankles. ${ }^{6}$ The neuromuscular abnormalities of cerebral palsy such as involuntary muscle contractions and movements also make it difficult to accurately measure the height of afflicted subjects and prevent them from remaining immobile while their body composition is being evaluated. Children with cerebral palsy cannot be evaluated from a nutritional point of view using conventional methods such as height and body mass because many of these children present growth retardation or abnormal body composition. ${ }^{8}$

In view of these points, the use of tables correlating weight and height alone is insufficient in these individuals, given that these tables cannot divide the whole-body weight into lean and adipose mass. This division of body mass is considered to be a fundamental resource generating physical training schemes. ${ }^{9}$

To study body composition, techniques involving procedures for direct, indirect and doubly indirect determination are used..$^{10}$ Although direct measurements of physical aptitude among children are preferred by doctors, occupational therapists and physiotherapists, such measurements may be impractical for some children, especially those with greater impairments. ${ }^{1}$

In adipose tissue measurement using kinanthropometry, variables measured unilaterally are obtained from the right half of the body in accordance with the recommendations of the Constitutional Anthropometry Committee of the Food and Nutrition Group of the United States National Research Council and of the International Standardization Committee for Physical Aptitude Tests. ${ }^{11}$

However, if there is accentuated asymmetry between the two halves of the body resulting from various pathological conditions and especially cerebral palsy, unilateral measurements may not reflect the real body composition. It has been reported that muscle deficits may alter fat deposition in the affected limbs, thus resulting in unrealistic determination of body composition. ${ }^{7}$ Lean mass measurements obtained from hemiplegic individuals by means of bioelectric impedance have been found to be different for the right and left halves of the body, with a consequent requirement to calculate the mean between the two halves of the body. ${ }^{1}$

Regarding the nutritional state in cases of cerebral palsy, concerns arise over not only obesity, but also malnutrition. It has been reported that spastic children of school age may give the impression of being either skinny or fat. ${ }^{12}$

Growth deficits and abnormal body composition are common findings among greatly handicapped children and adolescents. ${ }^{13}$ Handicapped children are frequently shorter than normal children of the same age and sex. Among children with cerebral palsy, smaller triceps skin folds, height and body mass can be observed; however, it is often uncertain whether these changes are a consequence of cerebral palsy or of chronic malnutrition. ${ }^{14}$

Nutritional studies on cerebral palsy patients with spastic quadriplegia have been inconclusive because they have typically used direct methods for measuring body composition and because both the adipose mass and lean mass determinations from anthropometric evaluations have been imprecise. ${ }^{15}$

Adults with cerebral palsy exhibit great variation in body composition (lean and fat), suggesting that nutritional problems noted among children with cerebral palsy persist with age. For this reason, it is essential for physicians to monitor the nutritional state of adults with cerebral palsy in order to implement appropriate nutritional interventions with the aim of preventing over- or under-nutrition. ${ }^{7}$

Adipose tissue measurements have been standardized for years and employ skin fold measurements taken from the right half of the body because it is believed that there is symmetry between the two halves of the body and because most individuals present right-side dominance. This leads to technical difficulty in performing this procedure in cases of cerebral palsy, especially among hemiplegic patients, due to the asymmetry between the two halves of the body. A comparative study between the skin folds of the dominant and nondominant halves of the body among patients with cerebral palsy and spastic hemiplegia may generate a solution to this problem.

One objective of the present study was to compare the skin fold measurements in millimeters and fat percentage obtained through the Guedes and Jackson-Pollock equations for dominant and nondominant halves of the body among patients with cerebral palsy and spastic hemiplegia. The other objective was to investigate whether there was any statistical correlation between the percentage fat obtained by means of DEXA (dual-energy x-ray absorptiometry) and the percentage fat obtained by means of prediction equations in the dominant and nondominant halves of the 
body and in relation to the mean between the two halves of the body.

\section{Sample and Methodology}

The study was approved by the Ethics Committee of Hospital das Clínicas (São Paulo, Brazil) and the sample was composed of 20 patients with cerebral palsy and spastic hemiplegia (group A) and 30 normal individuals (group B). The mean age of group A was $24.6 \pm 5.6$ years, ranging from 16.1 to 38.1 years, and the mean age of group B was $25.3 \pm 3.8$ years, ranging from 19 to 34.11 years. The sex distribution in the two groups was similar.

In group B (control group), the dominant side was determined according to which hand these individuals preferred for writing: $90 \%$ (27 individuals) presented right dominance. In group A, the dominant side was deemed to be the normal side. The right side was paralyzed in $65 \%$ (13 patients), and the left side was paralyzed in 35\% (seven patients).

Twenty patients presented with cerebral palsy of the spastic type, with hemiplegic distribution. Fifteen percent (three patients) presented with mild spasticity, and 85\% (17 patients) presented with moderate spasticity. None of the patients presented with severe spasticity. ${ }^{16}$

All body composition evaluations using the skin fold thickness technique were performed by the author. All the body composition evaluations using the DEXA technique were performed by experienced radiology technicians, and the reports were issued by the physician in charge of the service.

For both groups, the total body mass of each individual was measured in kilograms using a Welmy digital balance (model RIW 200). Heights were measured in centimeters using the stadiometer of the same digital balance. Skin fold thicknesses were measured in millimeters using Lange skin fold calipers. Regions proposed by Guedes ${ }^{10}$ and Costa ${ }^{17}$ were used to measure skin folds.

After the regions were defined, the thickness of the subcutaneous tissue was measured three times in each region for the dominant and nondominant halves of the body. These were subsequently used as the mode or calculated mean for each skin fold. After calculating the mode or mean for each skin fold, comparisons were made within and between the groups.

Whole-body bone densitometry for body composition was performed using a Lunar DPX Plus densitometer. Densitometry was performed on 19 of 20 patients in group A and 29 of the 30 volunteers in group B.

For comparison of nonparametric values, the Wilcoxon test was used for pairs of dependent samples and the MannWhitney U test was used for pairs of independent samples.
For comparison of different techniques for body composition evaluation, linear regression and ANOVA F-value tests were used. A significance level of 5\% was adopted for all comparisons $(\mathrm{P}=0.05 \%)$.

\section{RESULTS}

Comparisons between the dominant and nondominant halves of the body in group B revealed statistically significant differences in the following skin folds: biceps $(\mathrm{P}<0.0001)$, subscapular $(\mathrm{P}=0.0349)$, midaxillary $(\mathrm{P}=$ 0.0493), suprailiac $(P=0.002)$, abdominal $(P<0.0001)$, thigh $(\mathrm{P}<0.0001)$ and midcalf $(\mathrm{P}=0.0118)$. There were statistically significant differences in the fat percentage estimated using equations proposed by Guedes $(\mathrm{P}<0.0001)$, Jackson-Pollock for seven folds $(\mathrm{P}<0.0001)$ and JacksonPollock for three folds $(\mathrm{P}<0.0001)$.

The mean values in millimeters for all skin folds except the midcalf, and for the percentage fat obtained from the three equations, were found to be greater in the nondominant half of the body.

Comparisons between the dominant and nondominant halves of the body in group A revealed statistically significant differences in the following skin folds: biceps $(\mathrm{P}=0.0007)$, triceps $(\mathrm{P}=0.0003)$, thoracic $(\mathrm{P}=0.0319)$, suprailiac $(\mathrm{P}=0.0277)$, thigh $(\mathrm{P}<0.0001)$ and midcalf $(\mathrm{P}$ $=0.001)$. Statistically significant differences were found in the fat percentage estimated using equations proposed by Guedes ( $\mathrm{P}<0.0001)$, Jackson-Pollock for seven folds $(\mathrm{P}<$ $0.0001)$ and Jackson-Pollock for three folds $(\mathrm{P}=0.0003)$.

The mean values in millimeters for all skin folds except the midcalf, and for the fat percentage obtained from the three equations, were found to be greater in the nondominant half of the body.

Comparisons between the dominant halves of the body in groups A and B only showed a significant difference for the triceps skin fold $(\mathrm{P}=0.0455)$.

Comparisons of the differences in the dominant and nondominant halves of the body between groups $\mathrm{A}$ and $\mathrm{B}$ revealed significant differences for the biceps skin fold ( $\mathrm{P}$ $=0.0272)$, triceps skin fold $(\mathrm{P}<0.0001)$, thigh skin fold $(\mathrm{P}$ $<0.0001)$ and midcalf skin fold $(\mathrm{P}<0.0001)$, as well as the fat percentage estimated using the equations of Guedes $(\mathrm{P}<$ 0.0001), Jackson-Pollock for seven skin folds $(\mathrm{P}<0.0001)$ and Jackson-Pollock for three skin folds $(\mathrm{P}=0.0001)$.

The mean differences between the dominant and nondominant halves of the body for all skin folds except the subscapular and abdominal, as well as for the percentage fat, were greater in group A.

Statistically significant correlations in both groups were found for determination of the percentage fat using the 
DEXA technique and the equations of Guedes, JacksonPollock for seven skin folds and Jackson-Pollock for three skin folds with respect to the dominant and nondominant halves of the body and the mean value of the two halves of the body.

\section{DISCUSSION}

The literature suggests that single measurements of body mass, or of body mass and body height, are insufficient for determining obesity and malnutrition, since these measurements do not evaluate the constituents of the body and do not clarify whether "fat" or "skinny" individuals present adequate percentages of fat in relation to their total body mass. ${ }^{3,4,18}$ This inaccuracy may be worse for physically handicapped individuals whose neuromuscular abnormalities form part of their clinical condition and impede such measurement techniques. ${ }^{6-8}$

The insufficient data provided by weight/height tables, including the body mass index (BMI), justify evaluation of body composition, which can be performed using a variety of methods. Among known evaluation methods, we chose an indirect measurement technique because direct measurements are thought to be impracticable in humans, especially among those with greater impairment. ${ }^{18,19} \mathrm{We}$ chose adipose tissue measurement because of the advantages it presents over other techniques, because it is frequently used in Brazil, and because it achieves its proposed objectives at a low cost. ${ }^{3,10,11}$

We chose to use the Guedes equation because it was developed based upon studies of Brazilian populations, thus ensuring that skin fold calculations were specific to the population for which they were constructed. Furthermore, we used the Jackson-Pollock equations because they are the mostly widely used equations in the world, including in Brazil. $3,17,20$

We decided to study patients aged between 16 and 40 years to minimize the influence of bone growth or biological aging with respect to body composition. Despite the standard measurement of adipose tissue in the right half of the body, bilateral measurements were necessary in the present study because of the clinical characteristics of our patients, particularly the asymmetry between the two halves of the body. ${ }^{3,10,11}$ We also evaluated a control group in order to acquire normative values, using the same protocol for the control subjects as the test subjects.

The DEXA technique was used in order to make comparisons with the adipose tissue measurements. The aim was to correlate DEXA and adipose tissue measurement results with respect to the dominant and nondominant halves of the body and the mean of the two halves of the body.
In group $\mathrm{B}$, it was clear that the biceps, subscapular, midaxillary, suprailiac, abdominal, thigh and midcalf skinfold measurements were different between the dominant and nondominant halves of the body. This was contrary to what has been reported in the literature, which states that measurements should always be made in the right half of the body because there is little difference between the two halves. ${ }^{3,10,11}$

We also found a statistically significant difference in group B for percentage fat in the dominant and nondominant halves of the body when using the three prediction equations in this study.

For group A, biceps, triceps, thoracic, suprailiac, thigh and midcalf skin fold measurements were significantly different between the dominant and nondominant halves of the body. This coincides with the findings of Hildreth et al., who stated that muscle deficits may alter fat deposition in the affected limbs. ${ }^{7}$

The estimated percentage of fat was greater in the nondominant half of the body. Our findings coincide with those of Parker et al., who evaluated the body composition of patients with cerebral palsy and hemiplegia using the bioelectric impedance technique. ${ }^{1}$

When we compared the dominant half of the body between the two groups, only the triceps skin fold presented a statistically significant difference. This suggests that patients with cerebral palsy and spastic hemiplegia present greater metabolic activity in this region. This may be explained by the unilateral nature of functional activities that require extension of the upper limbs, such as getting up from the ground or from a chair.

Differences between the dominant and the nondominant halves of the body for biceps, triceps, thigh and midcalf skin folds, as well as the percentage fat, were significant when compared between group A and group B, with higher mean values in group A than in group B. This is an important finding among this population since it suggests that differences in the distribution of subcutaneous adipose tissue are greater in patients with cerebral palsy and spastic hemiplegia than in normal individuals. The larger difference between the halves of the body in group A than in group $\mathrm{B}$ also suggests that, when choosing the adipose tissue measurement technique for evaluating the body composition of this population, the mean between the two halves of the body should be used.

Both group A and group B showed statistically significant correlations between the results of DEXA and the three adipose tissue measurement equations used with respect to the dominant and nondominant halves of the body and the mean between the two halves of the body. This finding suggests that the percentage of body fat can be 
measured interchangeably by DEXA and adipose tissue measurement.

We also found in this population of adults that the body mass and height measurements were lower in group A. This coincides with reports that children with cerebral palsy exhibit retarded growth, that handicapped children and adolescents present growth deficits, and that nutritional problems noted among children with cerebral palsy may persist until adulthood. .,12-14 $^{2}$

Although it was not the main aim of our study, we were able to verify a difference between measurements of dominant and nondominant limbs of normal individuals (group B). This casts doubt on the currently accepted notion that measurements obtained only from the right half of the body are sufficient for analysis of body composition.

Through adaptation of adipose tissue measurement techniques for individuals with cerebral palsy, it may be possible to more effectively study body composition and the influence of nutritional adaptation and physical activity on this parameter.

\section{CONCLUSIONS}

There were statistically significant differences between the dominant and nondominant halves of the body in the biceps, triceps, thoracic, suprailiac, thigh and midcalf skin folds in group A as well as in the biceps, subscapular, midaxillary, abdominal, thigh and midcalf skin folds in group B.

In both groups, there were statistically significant differences in the percentage fat estimated by the Guedes and the seven- and three-skin-fold Jackson-Pollock equations when comparing the dominant and nondominant halves of the body.

The difference in skin folds and fat percentage between the dominant and nondominant halves of the body was greater in group A than in group B.

There were statistically significant correlations between DEXA and the Guedes and Jackson-Pollock prediction equations (seven and three skinfolds), in both group A and group B.

Data from group A suggest that the mean value of the two halves of the body should be used for adipose tissue measurement when evaluating body composition.

\section{REFERENCES}

1. Parker DF, Carriere L, Hebestreit H, Salsberg A, Bar-Or O. Muscle performance and gross motor function of children with spastic cerebral palsy. Develop Med Child Neurol. 1993;35:17-23.

2. Martin AD, Ward R. Body composition. In: Docherty D. Measurement in pediatric exercise science. Windsor: Human Kinetics; 1996. p. 88126.

3. Nieman DC. Body composition measurement. In: Nieman DC. Fitness and sports medicine: an introduction. California: Bull Publishing Company; 1990. p. 107-39.

4. Leite PF. Obesidade - Diagnóstico e classificação através do método antropométrico. In: Leite PF. Aptidão física: esporte e saúde. São Paulo: Robe Livraria e Editora; 1990. p. 189-204.

5. Pollock ML, Wilmore JH. Obesidade e controle de peso. In: Pollock ML, Wilmore JH. Exercícios na saúde e na doença: avaliação e prescrição para prevenção e reabilitação. Tradução de Maria Cristina A. de Souza. Rio de Janeiro: Medsi; 1993. p. 47-79.

6. Okamoto GA, Phillips TJ. Nutrição. In: Okamoto GA, Phillips TJ. Medicina física e reabilitação: princípios básicos. Tradução de Vilma Ribeiro de Souza Varga. São Paulo: Manole;1990. p. 66-8.

7. Hildreth HG, Johnson RK, Goran MI, Contompasis SH. Body composition in adults with cerebral palsy by dual-energy X-ray absorptiometry, bioelectrical impedance analysis, and skin fold anthropometry compared with the $18 \mathrm{O}$ isotope- dilution technique. Am J Clin Nutr. 1997;66:1436-42.

8. Azcue MP, Zello GA, Levi LD, Pencharz PB. Energy expenditure and body composition in children with spastic quadriplegic cerebral palsy. J Pediatr. 1996;129:870-6.
9. Marins JCB, Giannichi RS. Composição Corporal. In: Marins JCB, Giannichi RS. Avaliação e prescrição de atividade física: guia prático. Rio de Janeiro: Shape;1996. p. 43-46.

10. Guedes DP. Composição corporal: princípios, técnica e aplicações. Paraná: Apef; 1994

11. Rodrigues CEC, Carnaval PE. Fundamentos de cineantropometria. In: Rodrigues CEC, Carnaval PE. Musculação: teoria e prática. Rio de Janeiro: Sprint; 1986. p. 17-35.

12. Berg K, Isaksson B. Body composition and nutrition of school children with cerebral palsy. Acta Pediatr. Scand Suppl. 1970;204(Suppl):41.

13. Stallings VA, Zemel BS, Davies JC, Cronk CE. Charney EB. Energy expenditure of children and adolescents with severe disabilities: a cerebral palsy model. Am J Clin Nutr. 1996;64:627-34.

14. Bandini LG, Schoeller DA, Fukagawa, NK, Wykes LJ, Dietz, WH. Body composition and energy expenditure in adolescents with cerebral palsy or Myelodysplasia. Pediatr Res. 1991;29:70-7.

15. Stallings VA, Cronk CE. Zemel BS, Charney EB. Body Composition in children with spastic quadriplegic cerebral palsy. J Pediatr. 1995;126(5 Pt 1):833-9.

16. Carazzato JG. Paralisia cerebral. In: Hebert S, Xavier R. Ortopedia e Traumatologia: princípios e prática. Porto Alegre: Artmed;1995. p.31629.

17. Costa RF. CD-ROM Avaliação da composição corporal. Santos: FGA Multimídia, 1999. 
18. Monteiro JC. Obesidade: diagnóstico, métodos e fundamentos. Aspectos gerais. In: Halpern A, Matos AFG, Suplicy HL, Mancini MC, Zandella MT. Obesidade. São Paulo: Lemos;1998. p. 55-66.

19. Kiss MAPDM, Böhme MTS, Regazzini, M. Cineantropometria. In: Ghorayeb N, Barros Neto TL. Exercício: preparação fisiológica - avaliação médica - aspectos especiais e preventivos. São Paulo: Atheneu;1999. p.117-30.

20. Fox EL, Bowers RW, Foss ML. Exercício, composição corporal e controle ponderal. In: Fox EL, Bowers RW, Foss ML. Bases fisiológicas da educação física e desportos. Tradução de Giuseppe Taranto. Rio de Janeiro: Guanabara Koogan; 1991. p. 394-419.

21. Berg K. Remarks on physical training of children with cerebral palsy. Acta Paediatr Scand Suppl. 1971;217(Suppl):106-7.

22. Berg K. Heart- rate telemetry for evaluation of the energy expenditure of children with cerebral palsy. Am J Clin Nutr, 1971;24:1438-45.

23. Cameron N. The methods of axiological anthropometry. In: Falkner F, Tanner JM. Human growth. New York: Plenum Press;1986. p. 1-42.

24. Falkner JA Physiology of swimming and diving. In: Falls H. Exercise physiology. Baltimore: Academy Press; 1968.
25. Jackson AS, Pollock ML. Predicting accuracy of body density, lean body weight, and total body volume equations. Med Sports Sci Exerc. 1977;9:197-202.

26. Lima FR, Falco V. DEXA. In: Costa RF. CD-ROM Avaliação da composição corporal. Santos: FGA Multimídia; 1999.

27. McArdle WD, Katch FI, Katch VL. Composição corporal, equilíbrio energético e controle ponderal. In: McArdle WD, Katch FI, Katch VL. Fisiologia do exercício: energia, nutrição e desempenho humano. Tradução de Giuseppe Taranto. Rio de Janeiro: Guanabara Koogan; 1992. p. 387-475.

28. Parsons HG, Zamora SA. Bioelectrical impedance analysis for estimation of body water spaces. J Pediatr. 1997;131:500-1.

29. Pollock ML, Wilmore JH. Alterações da composição corporal com o exercício. In: Pollock ML, Wilmore JH. Exercícios na saúde e na doença: avaliação e prescrição para prevenção e reabilitação. Tradução de Maria Cristina A. de Souza. Rio de Janeiro: Medsi; 1993. p. 155-89.

30. Slaughter MH, Lohman TG, Boileau RA, Horswill CA, Stillman RJ, Van Loan MD, et al. Skin fold equations for estimation of body fatness in children and youth. Hum Biol. 1988;60:709-23. 